\title{
MAIN DIRECTIONS OF IMPROVING THE DEVELOPMENT OF TECHNOLOGY FOR MANUFACTURING PRODUCTS FROM POLYMER COMPOSITE MATERIALS BY THE METHOD OF WINDING
}

\author{
DING KAI JIAN, Cand. Sc. (Tech.)
}

Department of Processing Technology of Non-metallic Materials, State Educational Institution of Higher Professional Eeducation "Moscow Aviation Technology Institute - Russian State Technological University named after K.E. Tsiolkovsky", 3, Orshanskaya St., Moscow, 121552, Russia, tel. +007 8962-955-2330, e-mail: kjding222@163.com

Abstract. The development of scientific and technological progress in mechanical engineering, energy, aerospace and other industries is unthinkable without the creation of new structural materials that can improve the most important parameters of engines, machines and mechanisms, assemblies, devices and increase their mass performance, reliability, service life of products and reduce their material consumption. Products and aggregates from polymer composite materials (PCM) can be obtained in various ways. In industrial production, the most widely used method of winding and pressing. Pressing can be carried out using a mixture of preliminarily fiber and a polymer binder. One of the most promising methods of forming products and assemblies from a variety of plastic is the method of winding with fiber, due to the fact that it creates the required filler structure in the factories depending on their shape and operation characteristics. All areas of effective use of polymer composite materials are reflected. This article discusses the technological capabilities and applications of traditional and new varieties of the method. Even, the results of an analysis of the prospects for the development of manufacturing technologies for products and aggregates from polymer composite materials using the winding method are presented. There are methods of dry and wet winding. Consider these winding methods. Winding is carried out on a mandrel mounted on a machine with numerical control. This method is also called the spiral winding method. Existing approaches to the development of mathematical models are described and created for the manufacture of complex structural elements, including products and an assembly with a curved spatial axis, and so on.

Keywords: composite polymeric material; winding; pressure; fibre; reinforcing scheme; prepreg

\section{ОСНОВНІ НАПРЯМКИ ВДОСКОНАЛЕННЯ РОЗВИТКУ ТЕХНОЛОГІЇ ВИГОТОВЛЕННЯ ВИРОБІВ ІЗ ПОЛІМЕРНИХ КОМПОЗИЦІЙНИХ МАТЕРІАЛІВ СПОСОБОМ НАМОТУВАННЯ}

\author{
ДІН КАЙ ЦЗЯНЬ, $\kappa . m . н$.
}

Кафедра технології переробки неметалічних матеріалів, Федеральна державна бюджетна освітня установа вищої професійної освіти «МАТI - Російський державний технологічний університет імені К. Е. Ціолковського», вул. Оршанська, 3, 121552, Москва, Росія, тел. + 007 8962-955-2330, e-mail: kjding222@163.com

Анотація. Розвиток науково-технічного прогресу в машинобудуванні, енергетиці, авіакосмічній та інших галузях промисловості немислимий без створення нових конструкційних матеріалів, здатних поліпшити найважливіші параметри двигунів, машин і механізмів, агрегатів, приладів, підвищити їх масові показники, надійність, термін служби виробів і знизити їх матеріаломісткість. Вироби і агрегати 3 полімерних композиційних матеріалів (ПКМ) можна отримати різними способами. У промисловому виробництві найбільшого поширення набули методи намотування і пресування. Пресування може здійснюватися 3 використанням суміші попередньо нарубаного волокна і полімерного сполучного. Одним із найбільш багатообіцяючих методів формування виробів $\mathrm{i}$ агрегатів 3 різноманітного пластика виступає метод намотування волокном, за рахунок того, що він створює необхідну структуру наповнювача у фабрикатів залежно від їх форми й особливостей експлуатації. У статті описано сфери ефективного застосування полімерних композиційних матеріалів. Розглянуто технологічні можливості і галузі застосування традиційних і нових різновидів способу. Наведено результати аналізу перспектив розвитку технологій виготовлення виробів і агрегатів $з$ полімерних композиційних матеріалів за допомогою методу сухого та мокрого намотування. Намотування здійснюється на оправлення, встановлене на верстат із числовим програмним управлінням. Цей метод має також назву методу спірального намотування. Викладено існуючі підходи до розроблення 
математичних моделей, створених для виготовлення складнопрофільних елементів конструкцій, в тому числі виробів і агрегатів з вигнутою просторовою віссю.

Ключові слова: полімерний композиційний матеріал (ПКМ); намотування; пресування; волокно; схема армування; препрег

\title{
ОСНОВНЫЕ НАПРАВЛЕНИЯ СОВЕРШЕНСТВОВАНИЯ РАЗВИТИЯ ТЕХНОЛОГИИ ИЗГОТОВЛЕНИЯ ИЗДЕЛИЙ ИЗ ПОЛИМЕРНЫХ КОМПОЗИЦИОННЫХ МАТЕРИАЛОВ СПОСОБОМ НАМОТКИ
}

\author{
ДИН КАЙ ЦЗЯНЬ, $\kappa . m . ~ н$.
}

Кафедра технологии переработки неметаллических материалов, Федеральное государственное бюджетное образовательное учреждение высшего профессионального образования «МАТИ - Российский государственный технологический университет имени К. Э. Циолковского», ул. Оршанская, 3, 121552, Москва, Россия, тел. + 007 8962-955-2330, e-mail: kjding222@163.com

Аннотация. Развитие научно-технического прогресса в машиностроении, энергетике, авиакосмической и других отраслях промышленности немыслимо без создания новых конструкционных материалов, способных улучшить важнейшие параметры двигателей, машин и механизмов, агрегатов, приборов, повысить их массовые показатели, надежность, срок службы изделий и снизить их материалоемкость. Изделия и агрегаты из полимерных композиционных материалов (ПКМ) могут быть получены различными способами. В промышленном производстве наибольшее распространение получили методы намотки и прессования. Прессование может осуществляться с использованием смеси предварительно нарубленного волокна и полимерного связующего. Одним из самых многообещающих методов формования изделий и агрегатов из разнообразного пластика выступает метод намотки волокном, за счет того, что он создает требуемую структуру наполнителя в фабрикатах в зависимости от их формы и особенностей эксплуатации. В статье описаны области эффективного применения полимерных композиционных материалов. Рассмотрены технологические возможности и области применения традиционных и новых разновидностей способа. Приведены результаты анализа перспектив развития технологий изготовления изделий и агрегатов из полимерных композиционных материалов с помощью метода сухой и мокрой намотки. Изложены существующие подходы к разработке математических моделей, созданных для изготовления сложно-профильных элементов конструкций, в том числе изделий и агрегатов с изогнутой пространственной осью.

Ключевые слова: полимерный композиционный материал (ПКМ); намотка; прессование; волокно; схема армирования; препрег

Introduction. Currently, while the average use of composite materials in mechanical industry is estimated to vary from 1.5 to $2 \%$, in the majority of developed countries this rate can rise to $10-15 \%$. Today, the USA, Germany, France, Russia, China and the UK are considered the world leaders in developing technology and equipment for manufacturing composite materials. It is expected that the annual growth in composites consumption in the aerospace engineering and automotive industry could make up $8 \%, 6 \%$ respectively. Today, the fabrication of composites has become a strategic industry in many countries. For example, composites are extensively used in the shipbuilding industry (powerboat and yacht hulls), aircraft industry (aircraft hull parts), power systems engineering (wind energy converters), automotive industry (hull parts, car tuning, outflow valve), the construction industry (finishing materials, sanitary ware and bathroom equipment), mechanical manufacturing (pipes, containers, tanks) $[1 ; 2]$.

Filament winding technique for polymer composites has been applied across industries since the $1950 \mathrm{~s}$, since when this manufacturing technique has undergone further development, which allowed designing high-strength lightweight parts and units, mainly used in the aerospace industry. In the filament winding process, a band of continuous resinimpregnated fiber rovings or tows is wound under tension around a rotating mandrel in a preselected fiber orientation pattern to produce hollow continuous fiber-reinforced polymer composite parts. After curing, the mandrel is 
removed, leaving the hollow composite product. The shape of mandrel (circle, triangle, rectangle, or ellipse) determines the shape of the part or unit. For some products such as gas bottles, the mandrel is a permanent part of the finished product forming a liner serving as an inner sealing shell $[3 ; 4]$.

This method is used to produce revolutionary shaped products such as missile hulls, structural parts of engines in missiles and launch vehicles, submersible hulls, gun barrels, body shells, balloons, tanks, barrels, tubes, frames, air scoops, oar blades, etc.

There are several different types of filament winding processes. The simplest winding machines have two axes of motion, the mandrel rotation and the carriage travel (usually horizontal). This method is applied for producing cylindrical products of comparatively small diameter, for example fishing rods, golf club shafts, etc. This process involves winding filaments under tension over a rotating mandrel. The mandrel rotates around the spindle while a delivery eye on a carriage traverses horizontally in line with the axis of the rotating mandrel, laying down fibers in the desired pattern or angle. The most common filaments are carbon and are impregnated in a bath with resin as they are wound onto the mandrel. Depending on the resin system and its cure characteristics, often the rotating mandrel is placed in an oven or placed under radiant heaters until the part is cured. Once the resin has cured, the mandrel is removed or extracted. Although this method is quite simple and efficient, its drawback is that it cannot be applied for producing pipes of large diameter [5].

Thread winding machines are applied for manufacturing products with high stressdeformation and strength characteristics. This method depending on the initial state of the fabric applied has two technologies: dry filament winding and wet filament winding.

In the dry winding method, the reinforcement is in the preimpregnated form termed towpreg. After several layers are wound, the component is cured and removed from the mandrel. The heating devices heat the bonding agent applied to the fiber filler and transfer it into a viscous state. Dry winding creates high contact pressure in the molding area. The use of a prepreg, which can be stored for quite a long time, allows more precise filler/binder ratio, this way simplifying the technology of hybrid composites and improving environmental performance.

One disadvantage of the dry winding technology is the presence of a residual solvent in the binder, which is the reason for the decrease in the properties of the products received. At the same time, due to the use of solvents, the range of binder substances, including phenol formaldehyde, epoxyphenolic, epoxy, polyamide and resins, expands significantly. Another drawback of this technology is that the product is formed at the temperature of in the mandrel which is higher than the melting point of the binder. As a result, the composite may have cavities or voids caused by incomplete saturation of the filler by the binder, which is especially the case in fibers with a developed free surface [6-8].

In wet winding, the operations of impregnation of fibers and product forming are combined in one technological process. Glass, carbon and organic fibers are used as reinforcing fillers. The fiber picks up resin either by passing through a bath with a liquid binder or from a metered application system. An excessive bonding agent is returned by the spin rollers. The reinforcing fibre bundles from the creels or bobbins are fed through a series of guides and a tensioning system a further set of guide pins control the trajectory of the fibres onto a drum impregnator located in a resin bath. The individual components of the resin system (for example, epoxy and amine) are mixed manually in the required stoichiometric proportions before being poured into the resin bath. The impregnated fibres are directed to a traversing carriage and a 'D-eye' which gathers the impregnated fibre bundles into a ribbon prior to winding them onto a rotating mandrel. The carriage traverses horizontally along the length of the rotating mandrel, laying resinimpregnated fibres in a pre-determined fashion onto the mandrel. The desired winding angle of the fibres is achieved by controlling the traverse rate of the carriage and rotation speed of the mandrel. The amount of bonding agent remaining after impregnation is controlled by 
force on the pressure rolls. The required winding density is obtained by tensioning the harness. As the thickness of the product increases, the velocity ratio must be adjusted according to the reinforcement scheme. This circumstance determines the need for machines using numerical control so as to fabricate products with more stable properties.

The wet winding technology allows for the production of high-strength monolithic products. However, the inability to employ solvents causes technological difficulties in ensuring the required viscosity of the bonding agent. The viscosity of the bonding agent must be maintained at least while the molding cycle of one product or unit is in progress. The cause of a large loss of resin is its wastage when it comes into contact with the parts of the processing equipment. In wet filament winding technology, low-viscosity resins such as unsaturated polyesters, complex vinyl esters, low-molecular epoxy substances are employed.

Winding of a fibrous material over the mandrel is often accompanied by air seizure, which can result in the formation of cavities and heterogeneity in the composite structure, causing local destruction zones. Threads and towpregs consist of numerous elementary microfibers which tend to contain a large number of microscopic capillaries. Therefore, the primary task of impregnation is to replace air and moisture in those micro- capillaries with the resin. This process occurs according to the laws of the capillary effect, to overcome which requires creation of a pressure gradient in the capillary. Improved fiber impregnation requires the employment of resins with both lower viscosity and coefficient of surface tension. The solution to this problem appears to be fundamental for ensuring stable quality of composites.

Depending upon the winding nature of the reinforcing material, there are several types of winding patterns in composite product, including circumferential (also known as hoop winding), helical, polar, longitudinalcircumferential, crosswise, planar patterned winding and other. These reinforcement winding trajectories are studied in detail and extensively employed in manufacturing wound composite products with pre-defined properties.
Theoretically, when winding the fibers on a mandrel surface, it is possible to organize any the fiber trajectories and the resulting winding pattern. Yet empirically, there are objective restrictions to the winding trajectories when winding complex-profile composite parts. Knowledge of differential geometry is used to obtain the winding trajectories. Geodesics are defined as the shortest paths between two arbitrary points on a surface. They can simplify the calculation and the computational effort for obtaining winding trajectories on a surface. However, for design flexibility, the complete coverage of a mandrel surface, and especially for optimization purposes non-geodesic paths are used. Unlike geodesic paths, non-geodesic paths are not stable. Friction forces become essential to keep these paths from slipping and therefore the friction coefficient is a key parameter to be measured.

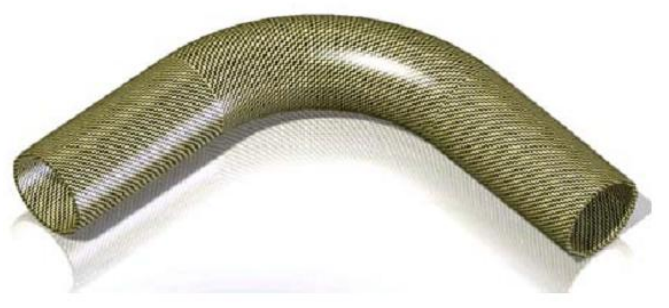

Fig. 1. Curved Axis Product Model

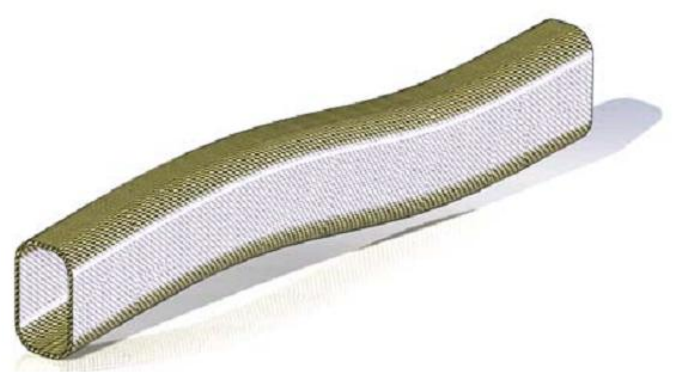

Fig. 2. Model of a complex product

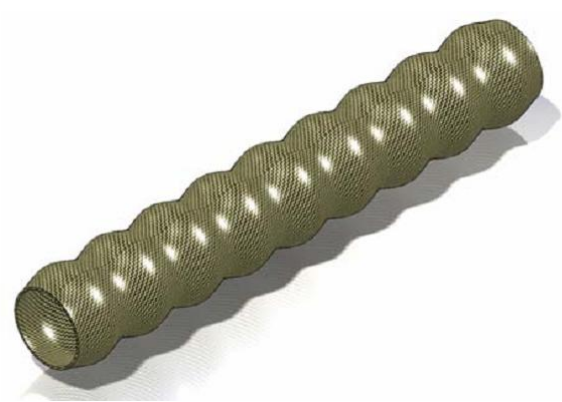

Fig. 3. Convex Concave Product Model 
There is specialized equipment designed to perform a certain winding technology. The majority of world manufacturers tend to be moving in two main directions regarding the improvements of winding equipment: the development of versatile machinery equipped with maximum additional winding means and variable geometry of operating area.

The objective number one at present is to develop winding composite technologies which are shown in Figures 1-3. Numerous designs of this type exist in contemporary aircraft and space engineering technology. However, there has been no experience of winding such composite parts and units in the world's practice yet, since the manufacturing procedure of these complex structures should be preceded by an ample array of research, design, technological and computation works.

Indeed, the development of complex structures should begin with formulating a general concept of the product, including computational and designing procedures of special technological and winding equipment. Product manufacturing procedures prove to have a significant impact on the physical and mechanical properties of composite material and the design parameters of the product created [9-11].

Meanwhile, new methods and applications of winding technology are being developed. One of them is perform/liquid molding. The features of this type of process could be described as follows. Unimpregnated fibres are initially made into part performs and then placed in assembled mold cavities or vacuum bags. With the aid of applied vacuum pressure the resins are injected and flow into the performs along the part plane. The technological parameters of this process include the density of the wound part, the time, the pressure and the temperature of the impregnation. The use of a vacuum bad allows the improvement of the quality of the external surface of products. This technology is proved to be promising, since it combines the advantages of winding and injection pressing.

A continuous technology of producing long-length composite parts from polymer composite materials combines stretching and winding of the spiral layer. The received product has a multi-directional reinforced structure. At the same time, the inner layer of the product consists of uniaxial-directed fibers, while the outer layer consists of spiral-directed fibers. Solid and hollow products appear to have a unique set of physical and mechanical characteristics.

Conclusion. Characterising the current state of the composite industry as a whole, it is noteworthy that domestic manufacturers of raw materials and equipment for composite materials are still lagging behind their international counterparts is. It is of utmost importance to develop the market segment of composite materials that is not yet entirely occupied, employing winding technology and equipment in mechanical engineering, metallurgy, the oil and gas, chemical and processing industries.

\section{REFERENCES}

1. http://ucci.ur.ru/press-center/news/yr2010/mn6/dy22/46

2. http://www.matrasurcomposites.com/articles/kompositny mir 2008.pdf

3. Bulanov I.M. and Sparrow V.V. Tekhnologiya raketnykh $\bar{i}$ aerokosmicheskikh konstruktsionnykh materialov [Technology of rocket and aerospace structural materials]. Moscow : Publishing House of MSTU named after N.E. Bauman, 1998, 516 p. (in Russian).

4. Vorobey V.V. and Evstratov S.V. Novyye napravleniya v sovremennoy tekhnologii namotki konstruktsiy iz kompozitsionnykh materialov [New directions in the modern technology of winding structures from composite materials]. Vestnik MAI [MAI Bulletin]. 2009, vol. 16, no. 1, pp. 61-72. (in Russian).

5. Uglerodnyye volokna [Carbon Fiber]. Edited by S. Simamura: Per. with Japanese. Moscow: Mir, 1987,304 p. (in Russian).

6. Grigoryev S.N. and Martinov G.M. Perspektivy razvitiya raspredelennykh geterogennykh sistem CHPU detsentralizovannymi proizvodstvami [Prospects for the development of distributed heterogeneous CNC systems by decentralized industries]. Avtomatizatsiya $v$ promyshlennosti [Automation in Industry]. 2010, no. 5, pp. 4-8. (in Russian). 
7. Grigoriev S., Melnik Yu. and Metel A. Broad fast neutral molecule beam sources for industrial - scale beam assisted deposition. Journal of Surface and Coating Technology. 2002, vol. 156, no 1-3, pp. 44-49.

8. Grigoriev S.N., Melnik Yu.A., Metel A.S, Panin V.V and Prudnikov V.V. Kompaktnyy istochnik para materiala provodyashchey misheni, raspylyayemoy ionami s energiyey $3 \mathrm{kev}$ pri davlenii 0,05 $\mathrm{Pa}$ [A compact source of steam of the material of a conducting target sputtered by ions with an energy of $3 \mathrm{keV}$ at a pressure of 0.05 Pa]. Pribory $i$ tekhnika eksperimenta. [Instruments and experimental technique]. 2009, no. 5, pp. 127-133. (in Russian).

9. Grigoryev S.N. and Borovsky V.G. Razrabotka tekhnologii naneseniya iznosostoykikh pokrytiy na rezhushchiy instrument na osnove mineralokeramiki i kubicheskogo nitrida bora [Development of technology for applying wearresistant coatings on cutting tools based on mineral ceramics and cubic boron nitride]. Obrabotka metallov: tekhnologiya, oborudovaniye, instrumenty [Metal processing: technology, equipment, tools]. 2003, no. 3, pp. 5-6. (in Russian).

10. Grigoryev S.N., Melnik Yu.A., Metel A.S. and Panin V.V. Istochnik shirokogo puchka bystrykh atomov, poluchayemykh pri perezaryadke ionov, uskoryayemykh mezhdu dvumya oblastyami, zapolnennymi plazmoy [Source of a wide beam of fast atoms obtained by recharging ions accelerated between two regions filled with plasma]. Pribory $i$ tekhnika eksperimenta [Instruments and experimental technique]. 2009, no. 4, pp. 166-172. (in Russian).

11. Metel A.S., Grigoryev S.N., Melnik Yu.A. and Panin V.V. Zapolneniye rabochey kamery tekhnologicheskoy ustanovki odnoorodnoy plazmoy s pomoshch'yu statsionarnogo tleyushchego razryada [Filling the working chamber of a technological installation with a uniform plasma using a stationary glow discharge]. Fizika plazmy [Plasma Physics]. 2009, vol. 35, no. 12, pp. 1140-1149. (in Russian).

\section{СПИСОК ВИКОРИСТАНИХ ДЖЕРЕЛ}

1. http://ucci.ur.ru/press-center/news/yr2010/mn6/dy22/46

2. http://www.matrasurcomposites.com/articles/kompositny mir_2008.pdf

3. Буланов И. М., Воробей В. В. Технология ракетных и аэрокосмических конструкционных материалов : монография. Москва : Изд-во МГТУ им. Н. Э. Баумана, 1998. 516 с.

4. Воробей В. В., Евстратов С. В. Новые направления в современной технологии намотки конструкций из композиционных материалов. Вестник МАИ. 2009. Т. 16, № 1. С. 61-72.

5. Углеродные волокна / под ред. С. Симамуры : пер. с япон. Москва : Мир, 1987. 304 с.

6. Григорьев С. Н., Мартинов Г. М. Перспективы развития распределенных гетерогенных систем ЧПУ децентрализованными производствами. Автоматизация в промышленности. 2010. № 5. С. 4-8.

7. Grigoriev S., Melnik Yu., Metel A. Broad fast neutral molecule beam sources for industrial - scale beam assisted deposition. Journal of Surface and Coating Technology. 2002. Vol. 156, № 1-3. Pp. 44-49.

8. Григорьев С. Н., Мельник Ю. А., Метель А. С., Панин В. В., Прудников В. В. Компактный источник пара материала проводящей мишени, распыляемой ионами с энергией 3 кэв при давлении 0,05 Па. Приборы $u$ техника эксперимента. 2009. № 5. С. 127-133.

9. Григорьев С. Н., Боровский В. Г. Разработка технологии нанесения износостойких покрытий на режущий инструмент на основе минералокерамики и кубического нитрида бора. Обработка металлов: технология, оборудование, инструментыл. 2003. № 3. С. 5-6.

10. Григорьев С. Н., Мельник Ю. А., Метель А. С., Панин В. В. Источник широкого пучка быстрых атомов, получаемых при перезарядке ионов, ускоряемых между двумя областями, заполненными плазмой. Приборы $u$ техника эксперимента. 2009. № 4. С. 166-172.

11. Метель А. С., Григорьев С. Н., Мельник Ю. А., Панин В. В. Заполнение рабочей камеры технологической установки одноородной плазмой с помощью стационарного тлеющего разряда. Физика плазмы. 2009. Т. 35, № 12. С. 1140-1149.

Надійшла до редакції 13.12.2019. 